\title{
SITUS WOTANNGARE-BOJONEGORO: NILAI PENTING DAN PENGEMBANGANNYA
}

\author{
WOTANNGARE SITE - BOJONEGORO: \\ ITS SIGNIFICANCE AND DEVELOPMENT
}

\author{
Hery Priswanto \\ Balai Arkeologi Yogyakarta \\ priswanto.balaryk@gmail.com
}

\begin{abstract}
Wotanngare site is believed to be the former Kingdom of Malawapati (Mlawatan Site) as well as the palace of King Anglingdarma. By local community, King Anglingdarma is a legendary and heroic figure for Bojonegoro society. This is supported by the toponym, toponyms related to Anglingdarma such as Budhug Village, Tibong Land, Kedhung Gandhu, Pathak Kedhung Buto, and Mount Pegat. Based on the results of the research carried out Balai Arkeologi Yogyakarta, Wotanngare Site in Bojonegoro regency is a settlement site Majapahit period. The archeological as well as the legend significance would be combined to contribute academically to the Bojonegoro community.
\end{abstract}

Keywords : Site Wotanngare, Legend, Archaeology, significance

\begin{abstract}
ABSTRAK
Situs Wotanngare diyakini masyarakat setempat sebagai bekas Kerajaan Malawapati (Situs Mlawatan) dan dianggap sebagai petilasan Prabu Anglingdarma. Anglingdarma merupakan seorang tokoh legendaris dan heroik bagi masyarakat Kabupaten Bojonegoro. Hal ini didukung dengan toponim-toponim yang berkaitan dengan tokoh Anglingdarma seperti Desa Budhug, Tanah Tibong, Kedhung Gandhu, Kedhung Pathak Buto, dan Gunung Pegat. Berdasarkan hasil penelitian Balai Arkeologi Yogyakarta Situs Wotanngare yang berada di Wilayah Kabupaten Bojonegoro merupakan sebuah situs permukiman masa Majapahit. Nilai penting secara legenda dan arkeologis akan dipadukan dalam upaya memberikan kontribusi bagi masyarakat Bojonegoro secara akademis.
\end{abstract}

Kata kunci: Situs Wotanngare, Legenda, Arkeologi, Nilai Penting

Tanggal masuk : 7 Februari 2013

Tanggal diterima : 26 April 2013 


\section{PENDAHULUAN}

Situs Wotanngare secara administratif berada di Pedukuhan Tawing, Desa Wotanngare, Kecamatan Kalitidu, Kabupaten Bojonegoro, Propinsi Jawa Timur yang berada pada $111^{\circ} 46^{\prime}$ 07.3" BT - $07^{\circ} 08^{\prime} 38.1^{\prime \prime}$ LS pada elevasi $52 \mathrm{~m}$ dpal. Desa Wotanngare merupakan salah satu dari 24 desa di Kecamatan Kalitidu. Letak Desa Wotanngare dari Kecamatan Kalitidu sekitar $2 \mathrm{~km}$ dan sekitar $13 \mathrm{~km}$ dari pusat pemerintahan Kabupaten Bojonegoro. Desa Wotanngare terdiri dari 5 dukuh yang meliputi 23 RT dan mempunyai luas wilayah 45,7442 ha. Dari luas tersebut sebagian besar merupakan lahan sawah $(42,32 \%)$ dan tegalan $(24,40 \%)$. Topografi Desa Wotanngare termasuk dataran rendah dengan ketinggian 25-100 $\mathrm{m}$ dpal. Kondisi Desa Wotanngare pada musim kemarau untuk lahan pertanian tampak kekurangan air, meskipun terdapat Waduk Dayakan dan dilalui Sungai Kalitidu dan Bengawan Solo. Sebaliknya bila musim hujan, waduk penuh dan sungai banjir akibat dari aliran Sungai Bengawan Solo. Untuk menanggulangi kekurangan air dalam mengolah lahan pertanian dilakukan cara pompanisasi. (Sukari 2009, 5).

Situs Wotanngare ini diyakini masyarakat setempat sebagai bekas Kerajaan Malawapati (Situs Mlawatan) dan dianggap sebagai petilasan Prabu Anglingdarma. Anglingdarma merupakan seorang tokoh legendaris dan heroik bagi masyarakat Kabupaten Bojonegoro, khususnya di Wilayah Kecamatan Kalitidu. Hal ini didukung dengan toponim-toponim yang berkaitan dengan tokoh Anglingdarma seperti Desa Budhug, Tanah Tibong, Kedhung Gandhu, Kedhung Pathak Buto, dan Gunung Pegat (Sukari 2009, 1). Berdasarkan keyakinan masyarakat tersebut pemeritah Kabupaten Bojongoro telah membangun sebuah pendapa di lokasi yang diyakini sebagai pusat kerajaan Malawapati serta sebuah pintu gerbang untuk menuju lokasi tersebut. (ibid.)

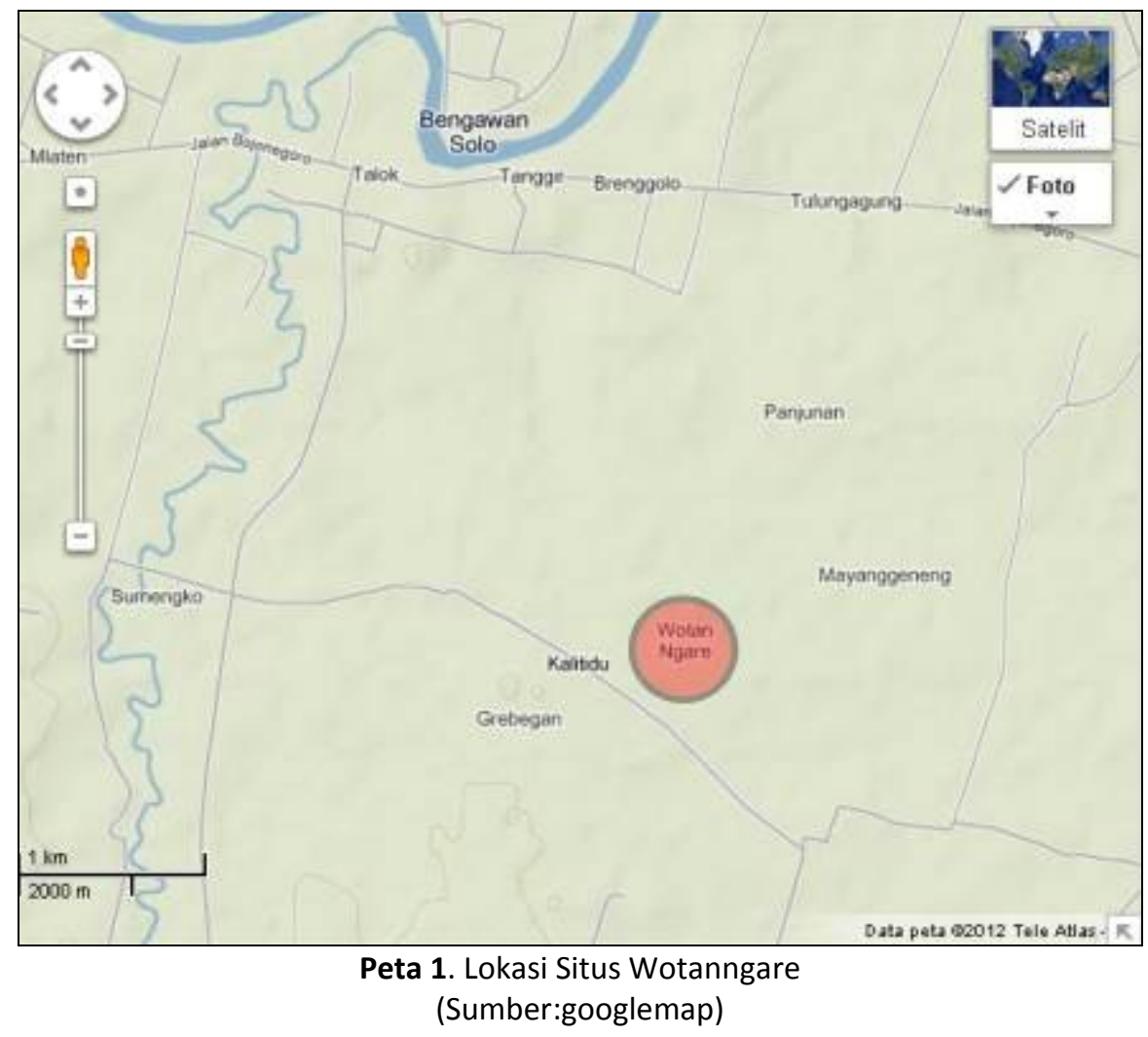




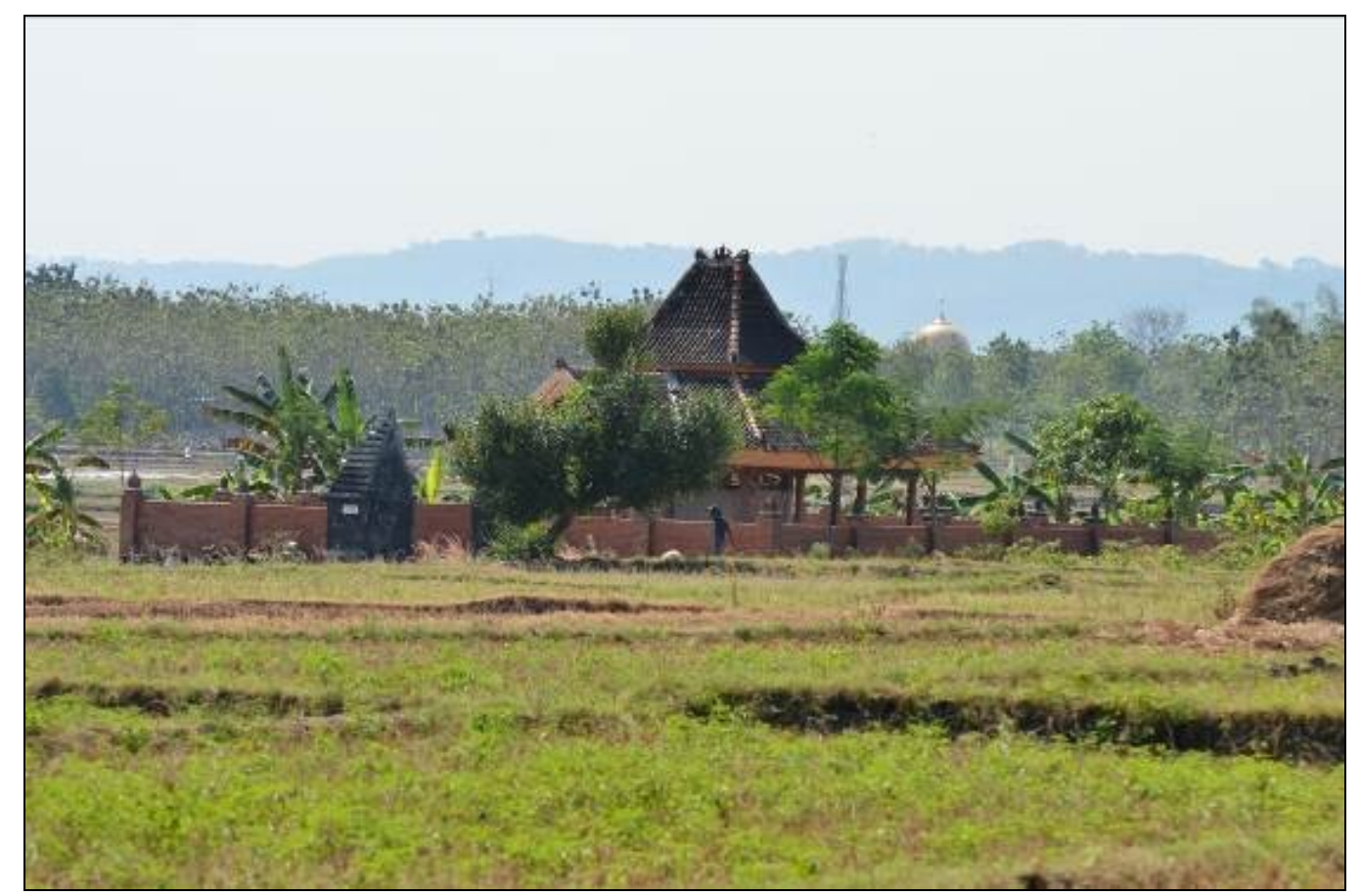

Foto 1. Pendapa yang diyakini masyarakat setempat sebagai pusat kerajaan Malawapati

(Dok. Balar YK-2012)

Pada tahun 1970 di lokasi Situs Wotanngare ini masih dijumpai bekas bangunan yang terbuat dari bata. Menurut keyakinan masyarakat setempat, batabata tersebut merupakan bata-bata kuna yang bukan berasal dari masa sekarang, berdasarkan ukuran bata yang ditemukan. Sampai pada tahun 1980, di sekitar situs Wotanngare masih dijumpai beberapa lokasi yang mengidentikkan Mlawatan sebagai lokasi bekas Kerajaan Malawapati, yaitu tanah Mbag, sumur lepan, besalen, dan lemah tibong (ibid.).

$$
\text { Riwayat Penelitian Situs }
$$

Wotanngare atau Mlawatan dalam berbagai kajian pernah dilakukan dalam kurun waktu hampir dua dasawarsa yaitu antara lain Tim Penyusunan Sejarah Kabupaten Bojonegoro tahun 1988, BPSNT tahun 2009, dan Balai Arkeologi Yogyakarta tahun 2012. Berikut akan dipaparkan mengenai riwayat penelitian Situs Wotanngare atau Mlawatan yaitu:

- Tim Penyusun Buku Sejarah Kabupaten Bojonegoro tahun 1988 Dalam buku Sejarah Kabupaten Bojonegoro (Menyingkap Kehidupan Dari Masa Ke Masa), Situs Wotanngare disebut sebagai puing- puing Mlawatan. Penyebutan itu didasarkan atas keberadaan bekas suatu bangunan yang terdiri dari bata-bata berserakan di Mlawatan yang berlokasi di tengah sawah. Tradisi setempat mengatakan bahwa peninggalan tersebut adalah bekas kraton kerajaan Malawapati di bawah Raja Anglingdarma.

- BPSNT Yogyakarta tahun 2009

Penelitian dengan fokus kajian pada studi antropologi (folklore) mengenai penelusuran jejak petilasan Anglingdarma di Mlawatan. Penelitian ini merupakan kerjasama antara BPSNT Yogyakarta dengan Pemerintah Kabupaten Bojonegoro c.q Dinas Kebudayaan dan Pariwisata Kabupaten Bojonegoro. Berdasarkan kajian yang telah dilakukan diperoleh informasi mengenai bentuk cerita Anglingdharma serta lokasi-lokasi yang berkaitan dengan cerita Anglingdharma. Hasil penelitian ini diwujudkan dalam bentuk buku yang berjudul "Executive Summary Penelusuran Jejak Petilasan Anglingdarma di Bojonegoro" 
- Balai Arkeologi Yogyakarta tahun 2012

Penelitian Situs Mlawatan atau Situs Wotanngare juga merupakan penelitian kerjasama dengan Pemerintah Kabupaten Bojonegoro c.q Dinas Kebudayaan dan Pariwisata Kabupaten Bojonegoro. Penelitian Situs Wotanngare bertujuan memperoleh informasi keberadaan tinggalan arkeologi yang berkaitan dengan penelusuran jejak petilasan Anglingdharma. berdasarkan hasil penelitian arkeologi diketahui bahwa di Situs Wotanngare dijumpai tinggalan arkeologi yang cukup signifikan. Data artefak secara kuantitas dan kualitias mengindikasikan bahwa Situs Wotanngare pernah digunakan sebagai permukiman. Sebagai data awal diduga kronologi permukiman di Situs Wotanngare sejaman dengan masa Majapahit. Hal ini berdasarkan temuan artefak seperti tepian jambangan berhias berbahan gerabah serta temuan mata uang kepeng yang merupakan salah ciri temuan masa Majapahit.

Tujuan penulisan artikel ini adalah untuk memberikan informasi terbaru mengenai Situs Wotanngare berdasarkan hasil penelitian Balai Arkeologi Yogyakarta. Hasil penelitian dengan fokus tinggalan arkeologi tersebut adalah sebagai bahan pembanding terhadap hasil-hasil penelitian terdahulu yang pernah dilakukan di Situs Wotanngare, sehingga akan diperoleh gambaran yang lebih faktual dalam rangka penelusuran jejak petilasan Anglingdharma. Hal ini penting untuk memenuhi harapan besar masyarakat Bojonegoro terhadap kejelasan tokoh Anglingdharma.

\section{SITUS WOTANNGARE DAN SITUS- SITUS ARKEOLOGI MASA PERADABAN HINDU BUDHA DI KABUPATEN BOJONEGORO}

Situs Wotanngare sebagai jejak peradaban masa Hindu-Buddha dalam rentang kewilayahan di Bojonegoro, jelas memiliki arti dan kedudukan yang penting.
Oleh karena itu berdasarkan keterkaitan dengan situs lain, secara makro situs ini ditempatkan dalam kerangka potensi yang tinggi namun secara mikro situs ini ditempatkan dalam kerangka potensi sedang (Tim Penelitian Balar Yk, 2012: 62). Situs Wotanngare tidak bisa dipisahkan dengan situs-situs arkeologi maupun temuan artefaktual masa peradaban Hindu Buddha di sekitar wilayah Kabupaten Bojonegoro. Data inventarisasi kepurbakalaan di Kabupaten Bojonegoro belum rekam secara komprehensif dan lengkap, sehingga untuk melacaknya cukup sulit. Di kemudian hari dipandang perlu menyusun sebuah monografi yang membahas mengenai kepurbakalaan masa Hindu Buddha di wilayah Kabupaten Bojonegoro. Di Kabupaten Bojonegoro banyak dijumpai tinggalan arkeologi dari masa peradaban Hindu Buddha (masa klasik) berupa arca, lumpang batu, yoni, lingga dan artefak lainnya yang sebagian tersimpan di Museum Nasional Jakarta, Museum Mpu Tantular Surabaya, dan Museum Rajegwesi Bojonegoro, serta tidak sedikit yang hilang sebelum diamankan.

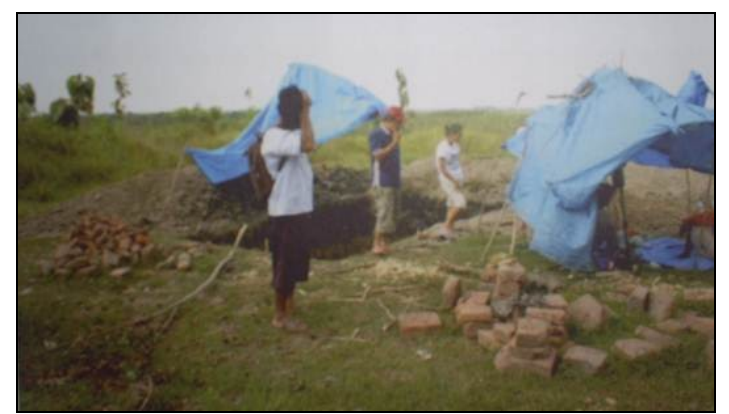

Gambar 1. Situs Alas Benda di Desa Ngeper, Kecamatan Padangan

(Sumber: Repro Buku Napak Tilas Wong Kalang Bojonegoro)

Bukti-bukti kesejarahan lainnya yang belum terungkap di antaranya adalah bekas fondasi bangunan kuna berbahan bata dengan ukuran yang cukup besar di Desa Soka dan Desa Buntalan Kecamatan Temayang. Di Situs Kwangen di Desa Leran - Kecamatan Kalitidu dijumpai sebaran fragmen gerabah dan keramik asing. Di Situs Alas Benda di desa Ngeper - Kecamatan Padangan dijumpai struktur bata dan batu 
putih terdiri dari 3 baris bata meliputi 7 susunan bata di atas batu putih. (Hoery 2011, 7-10). Sepanjang sejarah berdirinya Kabupaten Bojonegoro telah dijumpai 4 buah prasasti yaitu Prasasti Sekar (Kecamatan Sekar), Prasasti Sendang Sedati - 1478 M, Prasasti Adan-Adan 1301 M (Desa Mayangrejo, Kecamatan Kalitidu), dan Prasasti Pelem (Desa Pelem Kecamatan Purwosari). (ibid.). Namun sekian banyak temuan tersebut tidak memiliki keterangan yang lengkap atau hasil penelitian bahkan rusak akibat aktivitas penggalian liar untuk mencari benda-benda antik, sehingga bendabenda purbakala tersebut hanya menjadi saksi bisu sejarah Bojonegoro masa lalu.

\section{NILAI PENTING DAN PENGEMBANGAN WOTANNGARE SITUS}

Mengacu pada UURI nomor 11 tahun 2010 tentang cagar budaya yang mendefinisikan pengembangan cagar budaya sebagai upaya meningkatkan nilai, informasi, dan promosi cagar budaya serta pemanfaatannya melalui peneliotian, revitalisasi, dan adaptasi secara berkelanjutan dan tidak bertentangan dengan tujuan pelestarian.(Tim Penyusun, 2012: 29). Berkaitan dengan pengembangan Situs Wotanngare telah dilakukan penelitian awal dilakukan Balai Arkeologi Yogyakarta pada bulan Juni 2012 diperoleh informasi bahwa sebagai bagian dari jejak peradaban masa HinduBuddha dalam rentang kewilayahan di Bojonegoro, situs Wotanngare jelas memiliki arti dan kedudukan yang penting. Berdasarkan karakter dan kandungan data arkeologi, situs Wotanngare termasuk dalam kategori memiliki potensi cukup penting, khususnya dalam rantai sejarah kebudayaan masa pengaruh Hindu Buddha. Dengan hasil penelitian tahap awal ini untuk sementara dapat dijawab pertanyaan mengenai eksistensi Situs Wotanngare atau yang disebut oleh masyarakat setempat "Mlawatan" sebagai situs permukiman.

Letak Situs Wotanngare yang tidak jauh dari Bengawan Solo $\pm 3 \mathrm{~km}$ ke arah utara menjadi daya dukung bahwa Situs Wotanngare merupakan sebuah situs permukiman. Berdasarkan data Prasasti Trowulan diketahui bahwa sepanjang Bengawan Solo sejak sebelum tahun 1358 A.D. sudah ramai dengan permukiman. Hal ini membuktikan pentingnya pesisir di sepanjang Bengawan Solo sehingga banyak bermunculan permukiman-permukiman di sepanjang alirannya. Diduga permukiman awal di daerah Bojonegoro berada di sepanjang aliran Bengawan Solo. Bahkan dalam Prasasti Trowulan I (1358 A.D.) disebutkan nama-nama desa penambangan di tepi sungai yang berjumlah 74 buah Menurut Prof. H.M. Yamin, desa-desa tersebut selain terletak di tepi Sungai Brantas juga terdapat di tepi Sungai Bengawan Solo. (Utomo, 2009: 7).

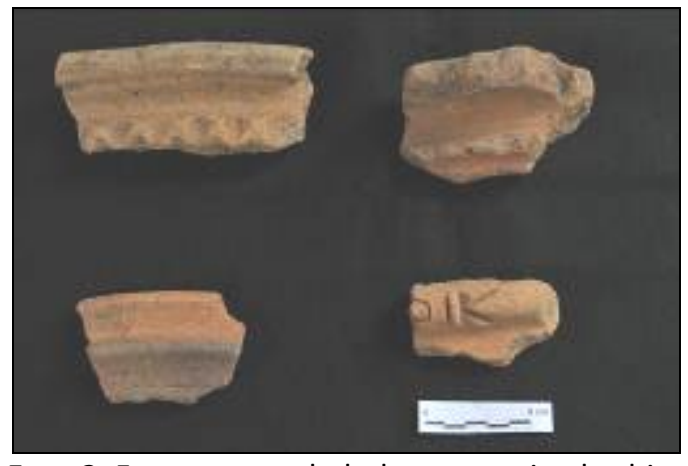

Foto 2. Fragmen gerabah dengan tepian berhias (Dok. Balar YK-2012)

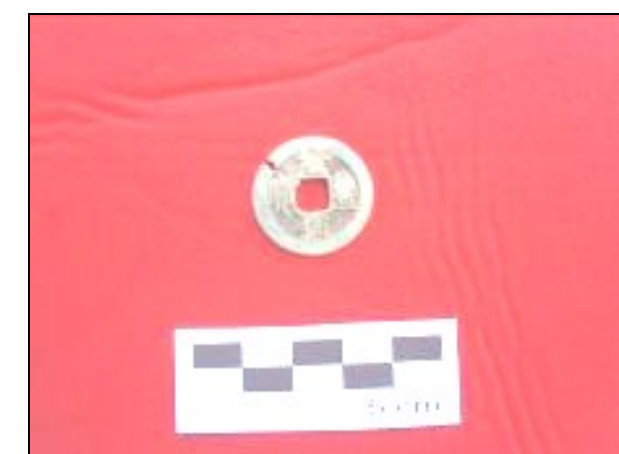

Foto 3. Mata Uang kepeng dari Situs Wotanngare (Dok. Balar YK-2012)

Beberapa temuan artefak hasil ekskavasi di anataranya berupa tepian jambangan yang secara morfologis mirip dengan artefak sejenis dari situs Trowulan yang sudah dikenal berasal dari masa Majapahit. Selain tepian gerabah berbentuk jambangan, temuan yang 
signifikan lainnya adalah mata uang kepeng. Identifikasi mengenai bentuk mata uang kepeng yang ditemukan di Situs Wotanngare ini mempunyai kesamaan dengan temuan sejenis di Situs-Situs Masa Majapahit yang salah satunya di Trowulan. Pada masa Majapahit, mata uang kepeng ini jumlahnya sangat banyak dan digunakan sebagai alat tukar dan satuan nilai dalam perdagangan. Hal ini mengindikasikan bahwa Situs Wotanngare sudah ada kontak dengan Majapahit, karena Bojonegoro memang merupakan salah satu bagian wilayah Majapahit.

Pada masa Majapahit dikenal 21 negara daerah yang merupakan bagian dari Kerajaan Majapahit, yang salah satunya adalah Matahun. Nama Matahun di Bojonegoro sudah dikenal pada masa Majapahit dan penguasa daerahnya disebut Bhre Matahun. Identifikasi dan lokasi Matahun terletak di bagian barat daerah Bojonegoro. Negara daerah Matahun disebut dalam Prasasti Kusmala (1272 C / 1350 M) dan Prasasti Waringinpitu (1369 C/ 1447) (Djafar, 2009: 164).

Sebagai penelitian tahap awal, hasil yang diperoleh belumlah seperti yang diharapkan banyak pihak. Namun dari hasil penelitian arkeologi ini diperoleh data berupa artefak (gerabah, keramik asing, mata uang kepeng) dan susunan bata kuna. Selain itu, beberapa narasumber menyampaikan bahwa di beberapa lokasi di Situs Wotanngare masih ditemukan struktur bata yang terpendam di dalam tanah. Situs Wotanngare masih merupakan lokasi yang menarik untuk diteliti dan dieksplorasi lebih lanjut dalam upaya melacak jejak kebesaran Majapahit di wilayah Bojonegoro. Berkaitan dengan pengembangan Situs Wotanngare dikemudian hari, dalam salah satu rekomendasi hasil penelitian diungkapkan bahwa pengembangan Situs Wotanngare sementara belum diprioritaskan mengingat masih banyak data yang perlu diungkap di area situs ini sehingga diperlukan sebuah penelitian lanjutan. Penelitian lanjutan ini diharapkan sebagai stepping stone untuk mengungkap historiografi Kabupaten Bojonegoro.

\section{PENUTUP}

Penelitian oleh Balai Arkeologi Yogyakarta di Situs Wotanngare akhirnya memberikan jawaban secara arkeologis bahwa Situs Wotanngare sebagai situs permukiman berdasarkan data artefaktual seperti tepian jambangan berhias dan mata uang kepeng bercorak masa Majapahit abad 14 - 15 Masehi. Hal ini tentunya sangat menarik karena Situs Wotanngare atau Mlawatan sudah dikaji dalam berbagai bidang dalam rangka mengungkap tokoh legenda masyarakat Bojonegoro yaitu Prabu Anglingdarma. Salah satu yang masih menjadi pertanyaan yaitu mengenai siapakah Prabu Anglingdarma ini? Apakah dia seorang tokoh historis atau legenda? 
Djafar, Hasan. 2009. Masa Akhir Majapahit - Girindrawarddhana Dan Masalahnya. Yogyakarta: Komunitas Bambu.

Hoery, J.F.X. 2011. Napak Tilas Wong Kalang Bojonegoro. Yogyakarta: DKKB - PSJB \& Elmatera Publishing.

Panitia Penggali \& Penyusunan Sejarah Hari Jadi Kabupaten Daerah Tingkat II Bojonegoro. 1988. Sejarah Kabupaten Bojonegoro (Menyingkap Kehidupan Dari Masa Ke Masa). Bojonegoro: Pemkab. DT II Bojonegoro.

Sukari, dkk. 2009. "Penelusuran Jejak Petilasan Anglingdarma di Bojonegoro". Executive Summary. Bojonegoro: Dinas Kebudayaan \& Pariwisata Kabupaten Bojonegoro.

Tim Penelitian. 2012. "Situs Mlawatan Desa Wotanngare, Kecamatan Kalitidu, Bojonegoro Jawa Timur. Laporan Peninjauan Arkeologi. Yogyakarta: Balai Arkeologi Yogyakarta.

Tim Penelitian. 2012. "Situs Wotanngare - Desa Wotanngare, Kecamatan Kalitidu, Bojonegoro Jawa Timur." Laporan Penelitian Arkeologi. Yogyakarta: Balai Arkeologi Yogyakarta.

Utomo, Danang Wahyu. 2009. Laporan Peninjauan Temuan Di Kecamatan Kalitidu, Kabupaten Bojonegoro. Mojokerto: Balai Pelestarian Peninggalan Purbakala. 
